\title{
Application of Advanced Light Microscopy to the Study of HIV and Its Interactions with the Host
}

\author{
Saveez Saffarian $1,2,3$ (D) \\ 1 Center for Cell and Genome Science, University of Utah, Salt Lake City, UT 84112, USA; \\ Saffarian@physics.utah.edu \\ 2 Department of Physics and Astronomy, University of Utah, Salt Lake City, UT 84112, USA \\ 3 School of Biological Sciences, University of Utah, Salt Lake City, UT 84112, USA
}

check for updates

Citation: Saffarian, S. Application of Advanced Light Microscopy to the Study of HIV and Its Interactions with the Host. Viruses 2021, 13, 223. https://doi.org/10.3390/v13020223

Academic Editor: Cristina Risco

Received: 4 January 2021

Accepted: 27 January 2021

Published: 1 February 2021

Publisher's Note: MDPI stays neutral with regard to jurisdictional claims in published maps and institutional affiliations.

Copyright: (c) 2021 by the author. Licensee MDPI, Basel, Switzerland. This article is an open access article distributed under the terms and conditions of the Creative Commons Attribution (CC BY) license (https:/ / creativecommons.org/licenses/by/ $4.0 /)$.

\begin{abstract}
This review highlights the significant observations of human immunodeficiency virus (HIV) assembly, release and maturation made possible with advanced light microscopy techniques. The advances in technology which now enables these light microscopy measurements are discussed with special emphasis on live imaging approaches including Total Internal Reflection Fluorescence (TIRF), high-resolution light microscopy techniques including PALM and STORM and single molecule measurements, including Fluorescence Resonance Energy Transfer (FRET). The review concludes with a discussion on what new insights and understanding can be expected from these measurements.
\end{abstract}

Keywords: HIV; iPALM; PALM; STORM; STED; TIRF; Gag; ESCRTs

\section{Philosophical Discord}

As Arthur Kornberg famously declared "Depend on viruses to open windows" [1], it is therefore not surprising that in the most fundamental quest for understanding Biology, viruses have played a fundamental role and inspired the last two generation of scientists. After the biochemical revolution of the Kornberg's generation, structural Biology found its footing in viral structures. The amazing symmetry of these structures [2] allowed structural Biology to refine its toolkit and become fundamental in understanding Biological processes [3]. While it is rewarding to focus on our success, it is important to conceptualize the challenge. In the writer's opinion, the most fundamental challenge is the failure of human brain to understand dynamics of any system with more than three simultaneously interacting parts, which covers almost all Biological processes. This frustration is not new, I would argue it is the fundamental challenge which drove Ramón Cajal to urge his acolytes to focus primarily on reproducibility as the fundamental goal of their scientific endeavor while avoiding creating theories [4]. Are we finally advanced enough to understand the full impact of all molecular dynamics on biological systems? Can viruses lead the way?

This review is primarily focused on the advanced imaging methods for study of human immunodeficiency virus (HIV) and the above questions are too fundamental to be addressed here, nevertheless, given the depth of HIV literature, at the end of the review, a discussion as to how advanced microscopy can be helpful in developing a more complete understanding of complex biological dynamics will be presented.

\section{HIV Assembly, Budding, and Maturation}

Immature HIV virions assemble on the inner leaflet of the plasma membrane, during assembly, two copies of the RNA genome, 2000 copies of Gag and 100 copies of GagPol, along with HIV accessory proteins are packaged into the immature virions whose membrane is also decorated with HIV Env proteins [5]. The release of these immature virions from the cell ( $140 \mathrm{~nm}$ in diameter) is catalyzed by Endosomal Sorting Complexes Required for Transport (ESCRT) [6-9]. After release, the HIV virions undergo a process of maturation catalyzed by the HIV protease [10-13], a delay in release of the immature virions 
results in an untimely activation of the protease and release of non-infectious particles [14]. Many molecular interactions within the immature as well as mature capsid of HIV have been mapped out [15-18]. We will here focus on the advanced imaging techniques which have been utilized to observe the dynamics by which these molecules come together to form the immature HIV virions and lead to its maturation.

\section{Total Internal Reflection Fluorescence (TIRF) Microscopy Measurements of HIV Virion Assembly}

Originally developed by Daniel Axelrod in the 1980s for observation of cellular membranes $[19,20]$, Total Internal Reflection Fluorescence (TIRF) Microscopy has played a crucial role in understanding the dynamics of HIV assembly and budding. HIV assembly was observed on the plasma membrane of live cells using TIRF microscopy, both through tagging the HIV Gag at its C-terminus with GFP and observing the assembly dynamics by monitoring formation of virus like particles [21] or tracking the assembly of virions with GFP inserted in between the MA and CA domains of Gag [22,23], both of which reported stochastic spontaneous nucleation of Gag on the plasma membrane followed by assembly of virions through addition of Gag molecules following a sigmoidal curve lasting 5-10 min. Using TIRF microscopy as well as photo-switching it was also possible to confirm that new HIV Gag molecules arrive at the assembly site through cytosol while human T-lymphotropic virus (HTLV) Gag assembles by recruiting additional Gag molecules from the adjacent plasma membrane [24]. The evanescent filed generated in TIRF mode can be well calibrated and used as a tool to measure the distance molecules travel away/towards the glass/media interface, this aspect of the TIRF microscopy was significantly developed during study of endocytosis $[25,26]$ and applied to study the assembly of HIV demonstrating the coupling of curvature creation and Gag polymerization during HIV assembly [27].

\section{Two Color TIRF Microscopy and Timing of Recruitment of Co-Factors}

It is needless to say that a major advantage of fluorescent microscopy is the specificity in which cellular components (proteins, lipids, sugars, or nucleic acids) could be linked to a particular fluorescent molecule and therefore be identified spectrally using the fluorescence emission [28]. One of the major advantages of live imaging is therefore simultaneous imaging of multiple components. Although it is possible to separate fluorescence from many fluorescent proteins simultaneously using interlaced pulsed excitation and lifetime gated detection $[29,30]$, these methods require time resolved detection which are impractical for wide field imaging. The emission spectra of fluorescent proteins therefore set a practical limit on the number of proteins which can be identified simultaneously. Given that the emission spectra are typically between $50-75 \mathrm{~nm}$ wide and the fluorescent molecules can be chosen with emissions between $500-700 \mathrm{~nm}$, this yields 2 and or 3 fluorescence channels that can be spectrally resolved [31].

\subsection{Following HIV Genome}

Having characterized the Gag recruitment during the assembly of HIV virions, it became possible to use the Gag signal as a marker to time the arrival of different viral components including the RNA genome and various ESCRT components with respect to the stages of assembly. Tracking of mRNA in cytosol became possible by the introduction of a bacteriophage MS2 binding sites into the mRNA sequence while expressing MS2-eGFP in the cells [32-34]. Using this technology and two color TIRF, an MS2 tagged partial genome of HIV was tracked during the assembly of the Gag VLPs in live cells and it was shown that the genome arrives very early during the assembly process [35] using similar technology, the genomic RNA was also tracked during its egress from the nucleus [36]. While these experiments are very informative, they are only possible due to the incorporation of a large number ( 24) MS2 binding sites into the genomic RNA, whose effects on localization should be considered. 


\subsection{Recruitment of ESCRTS}

The timing of arrival of ESCRT components is crucial for understanding HIV release. However, the labeling strategy in fluorescent microscopy is of essential importance. For example, many of the ESCRT proteins act as dominant negative when overexpressed in their GFP fused form [37]. Fluorescently tagged ESCRTs are better tested for their functionality in separate assays before they can be used in live imaging experiments $[27,38,39]$. Creating cell lines with full replacement of all wild type proteins with fluorescently tagged proteins is also helpful in establishing the functionality of the proteins and in addition allow quantification of number of molecules recruited at any given moment $[40,41]$. Using these methodologies, the recruitment dynamics of ALIX, TSG101, CHMP4b, and VPS4, all members of ESCRTs have been established with respect to Gag assembly dynamics [38-40,42-44]. Significant challenges, however, remain, these include observation of budding events in more physiologically relevant cell lines and in particular detection of the exact moment of viral release and its corresponding temporal relationship with recruitment of ESCRTs [45]. Further advances in developing new methodologies are required to parse out the exact mechanism by which ESCRT components catalyze the release of infectious HIV virions.

\subsection{HIV Capsids}

Single molecule TIRF microscopy was used to observe the disassembly of HIV mature capsids in vitro. In these experiments virions are immobilized and permeated on glass cover slips and disassembly of the mature capsid is observed by following the fluorescence signal versus time [46]. These experiments created a useful assay to observe the effects of IP6 and other protein-protein interactions on the dynamics of disassembly $[17,47]$.

TIRF microscopy and specially two color TIRF are therefore very practical techniques that can establish the arrival of molecules within a diffraction limited spot on the microscope, in its most common applications however, TIRF microscopy is limited by the resolution of the optical microscopy.

\section{Review of High-Resolution Optical Microscopy Techniques}

The wave nature of light limits the resolution of any optical microscope to within $\frac{\lambda}{2 n \operatorname{Sin}(\varnothing)}$, in which $\lambda$ is the wavelength of light, $\mathrm{n}$ is the index of refraction, and $\theta$ is the collection angle of the lens [28]. For visible light, the resolution of light microscopy is $\sim 250 \mathrm{~nm}$ which is much larger than the $140 \mathrm{~nm}$ size of HIV virions. High resolution microscopy has been developed to break the diffraction limit and has two general categories, the first are the methods that utilize engineering of excitation and emission paths utilizing non-linear or interferometric effects to increase the resolution, these methods include stimulated emission depletion (STED) [48], 4 Pi microscopy [49], and structured illumination microscopy (SIM) [50]. These methods are advantageous because they resolve all fluorescent molecules within the sample simultaneously. In contrast the second category of super-resolution techniques depend on the stochastic excitation and detection of single molecules within the sample. These methods mainly utilize that light collected from an object is emanating from a single molecule, the point spread function can be fitted and the location of the single molecule can be determined with nanometer accuracy depending on the number of photons registered from the particle [51]. Once it was discovered that florescent proteins could be switched from an "off" state to an "on" state given an activating pulse of laser [52], these two methods got combined to create stochastic localization microscopy techniques which include Photoactivatable Localization Microscopy (PALM) [53] and Stochastic Optical Reconstruction Microscopy (STORM) [54]. While the first incarnations of these methods were mainly improving the resolution within the focal plane of the microscope, a series of technical advances allowed improvements in the axial resolution of techniques including 3D STORM ( $\sim 50 \mathrm{~nm}$ axial resolution) [55] F-PALM ( $\sim 50 \mathrm{~nm}$ axial resolution) [56] and interferometric PALM (iPALM) ( 10 nm axial resolution) [57]. 


\section{Applications of High-Resolution Optical Imaging in HIV Biogenesis}

What are the most interesting informational content that can be derived from high resolution optical imaging? After all, cryotomography achieves far greater resolution than any optical microscope, so why bother? The answer is twofold, one is specificity and the other is dynamics. Since optical high resolution is fluorescence based and fluorescence can be introduced via genetic tags, high resolution optical imaging can be utilized in fixed samples to resolve the relative positions of two sets of molecules. Again, in this context, HIV Gag is the favorite target and for example positions of ESCRT components, ALIX, CHMP4 and VPS4 were measured with respect to HIV Gag localization with nanometer precision using PALM based techniques [40,58,59]. Aside from ESCRTs, STED microscopy was used to measure the localization of ENV proteins on the surface of mature/immature HIV virions [60]. While these experiments are very informative, the dynamics of the detected structures remain unresolved.

As mentioned, high resolution microscopy also has the capability of resolving the dynamics of viral components. This allows tracking of single molecules in and around HIV virions which includes the measurement of diffusion of HIV Gag molecules into the budding HIV Gag VLPs performed using a combination of PALM single molecule tracking and TIRF microscopy [61]. Individual ENV proteins on the surface of budding HIV virions have also been tracked using iPALM microscopy [62], a combination of these tracking algorithms along with identification of molecular interactions in the cytoplasmic tail of ENV and HIV Gag promise a live observation of such interactions [61,62].

One of the fundamental challenges in the study of HIV maturation has always been synchronization, since both assembly, release, and maturation are all stochastic processes, it is hard to parse one event out of the three for detailed measurements in bulk. Single virion assays however promise to overcome this obstacle by focusing on one virion at a time. Utilizing a light deactivated maturation inhibitor [63], STED was used to time the process of re-organization of Gag during maturation whose half-life was measured to take $30 \pm 10 \mathrm{~min}$ [64]. In principle it is possible to couple these measurements with fast freezing approaches and cryotomography which would provide further details within these structures in coming future.

What molecular interactions and dynamics play a role in activating the HIV protease has been a fundamental question. Recently iPALM microscopy was used to detect dynamics within the immature lattice of HIV [65], it is not clear if these dynamics are necessarily involved in the activation of the protease, however the data is suggesting further biochemical and structural validation coupled with iPALM microscopy will likely answer these questions.

It is therefore fair to conclude that the high-resolution microcopy techniques offer a very strong toolset for the study of HIV virions, further coupling of these techniques with each other and biochemical and structural analysis will likely uncover new biological mechanisms.

\section{Fluctuation Spectroscopy Techniques}

There is likely no other technique which utilizes the dynamic nature of biological processes as well as fluctuation-based measurements. Fluctuation spectroscopy is based on the Onsager principle and fluctuation dissipation theorem [66] and states that all important kinetic rates within a biochemical process can be measured by following the fluctuations within the system. Fluorescence correlation spectroscopy (FCS) pioneered by Elson and Web in 1970s applied this principle to measurements of fluorescence fluctuations and successfully measured kinetics of protein-DNA binding and diffusion [67]. FCS was plagued by the microscope objective design, specifically the non-infinity corrected objectives, therefore Elson and co-workers created Fluorescence Recovery after Photobleaching which later became more known as FRAP to get more relevant cellular data in the 1980s and 1990s [68]. The introduction of infinity corrected objectives and the dawn of single molecule detection revived the FCS as a relevant technique applied to the study of cellular dynamics [69]. In 
addition to the temporal analysis of the fluorescence fluctuations, analysis of moments of fluorescence revealed that fluctuation can inform both dynamics as well as the brightness of molecules [70-72]. Fluctuation spectroscopy can now be applied in raster scanning confocal as well as TIRF to detect cellular connectivity maps as well as diffusion coefficients, brightness distribution of fluorescence molecules in cellular environments [51,73-78]. In advanced theoretical analysis, higher order moments of fluctuations can be used to probe out of equilibrium processes which may turn out to be very useful if detected in Biological processes [79-83]. Techniques to measure fluctuations within a system in a parallel fashion are currently under development [84].

\section{Application of Fluctuation Spectroscopy to HIV Biology}

The brightness analysis enabled by fluctuation spectroscopy enabled the measurement of the number of Gag molecules packaged in the immature lattice of HIV virions. At the time, there was significant interest in understanding whether the immature lattice of HIV is fully packed as was early on proposed [85]. FCS measurements were used to detect the diffusion of Gag molecules and Gag-Gag interactions in cytosol [86]. The measurements of brightness on freely diffusing HIV Gag-eGFP VLPs demonstrated that the measured brightness per virion which corresponded to 1000-2000 Gag-eGFP/VLP is far below the expected full packaging of 5000 Gag-eGFP/VLP [87], these measurements were also confirmed by cryotomography [88]. More recently the brightness distribution was used within the cytosol to detect the state of oligomerization of Gag during HIV budding [89]. A combination of STED and scanning FCS was also used to detect the dynamics of PIP2 during early stages of HIV assembly [90,91]. Fluctuation spectroscopy therefore offers both measurements of dynamics as well as status of molecular aggregates which can be very informative for the study of HIV budding and maturation.

\section{Fluorescence Resonance Energy Transfer (FRET)}

When a fluorophore absorbs a photon, the electronic state of the fluorophore transitions to the excited state. In many cased this excited electron decays back to the ground state through generation of heat, and in some cases the electron emits a photon with a slightly lower energy which will be detected as a stoke shifted fluorescence signal [28]. If, however, there exists a fluorophore with a slightly smaller excitation energy gap at very close vicinity of the excited fluorophore, the energy within the excited fluorophore tunnels into the second fluorophore in a process significantly dependent on the two fluorophores distances and dipole orientations $\left(R_{0} / R\right)^{6}$ in which $R_{0}$ is $\sim 5-10 \mathrm{~nm}$. When the second fluorophore relaxes to its corresponding ground state, a photon is emitted which is characteristic of the florescence from the second fluorophore, this process is called Fluorescence Resonance Energy Transfer (FRET) [28,92]. FRET is a very precise molecular ruler with a range of 3-10 nm. This range makes it ideal for detecting the conformational conformations of macromolecules. It is not therefore surprising that single molecule FRET was developed rapidly to visualize protein and DNA-Protein interactions [93-95]. FRET has been used efficiently to detect conformational changes during binding of HIV Gag to membrane [96] as well as conformational dynamics within single HIV ENV proteins [97-99]. The observation of these conformational states coupled with their interactions with neutralizing antibodies promises very interesting studies soon.

\section{Other Significant Methodologies}

This review is by no means comprehensive since there are so many create ways to mix and combine advance light imaging experiments to measure significant biological processes. Specifically, the author would like to point out the methodologies developed to visualize viral entry and early infection which are a critical aspect of HIV biology which are mostly reviewed elsewhere [100-103]. 


\section{Outlook and Future Promises}

What is the premise and limitation of advanced optical methodologies? Would advance optical imaging have a fundamental impact on our understanding of virus biology, at the same level as biochemistry and structural biology? After all, the significant contribution of biochemistry is evident, since an annual detection of metabolites in blood is the most critical tool in diagnosis of a variety of diseases. In parallel, almost all small molecule inhibitors have tremendously benefitted from structural biology. Can advanced light microscopy ever achieve such physiological relevance?

While the answer to the above question will become naturally clear in the next decades, the fundamental power of advanced light microscopy techniques is in measuring dynamics in biological processes far away from equilibrium. While detailed protein-protein and enzymatic reactions identified by biochemistry and structural biology would always be valid, there is no guarantee that these interactions are playing out as we conceive them in biological processes, after all, all models build by our human brains are limited to keeping focus only on a few reactions at a time. It is therefore at least conceivable that multipoint multi component live imaging approaches, powered by advanced light microscopy techniques, coupled with advances in artificial intelligence, could uncover new pattern dynamics. In principle, these dynamics would not be easily visualized by man maid theoretical models and cannot be deduced from biochemical and structural data alone. Would understanding of these patterns contribute enough to be useful as a diagnostic or medicinal process? The question will remain to be answered in the next few decades.

Funding: This work was supported by R01 AI150474 grant to SS.

Acknowledgments: I am grateful for fruitful discussion with Michael Vershinin and members of the Saffarian lab.

Conflicts of Interest: The author declares no conflict of interest.

\section{References}

1. Kornberg, A. Ten Commandments: Lessons from the Enzymology of DNA Replication. J. Bacteriol. 2000, 182, 3613-3618. [CrossRef]

2. Caspar, D.L.; Klug, A. Physical Principles in the Construction of Regular Viruses. Cold Spring Harb. Symp. Quant. Biol. 1962, 27, 1-24. [CrossRef]

3. Harrison, S.C. Whither Structural Biology? Nat. Struct. Mol. Biol. 2004, 11, 12-15. [CrossRef]

4. Cajal, R. Advice for a Young Investigator; MIT Press: Cambridge, MA, USA, 1999.

5. Briggs, J.A.G.; Kräusslich, H.-G. The Molecular Architecture of HIV. J. Mol. Biol. 2011, 410, 491-500. [CrossRef]

6. Demirov, D.G.; Freed, E.O. Retrovirus Budding. Virus Res. 2004, 106, 87-102. [CrossRef]

7. Votteler, J.; Sundquist, W.I. Virus Budding and the ESCRT Pathway. Cell Host Microbe 2013, 14, 232-241. [CrossRef]

8. Bieniasz, P.D. Late Budding Domains and Host Proteins in Enveloped Virus Release. Virol. 50th Anniv. Spec. Issue 2006, 344, 55-63. [CrossRef]

9. Weissenhorn, W.; Göttlinger, H. Essential Ingredients for HIV-1 Budding. Cell Host Microbe 2011, 9, 172-174. [CrossRef]

10. Lee, S.-K.; Potempa, M.; Swanstrom, R. The Choreography of HIV-1 Proteolytic Processing and Virion Assembly. J. Biol. Chem. 2012, 287, 40867-40874. [CrossRef]

11. Konnyu, B.; Sadiq, S.K.; Turanyi, T.; Hirmondo, R.; Muller, B.; Krausslich, H.G.; Coveney, P.V.; Muller, V. Gag-Pol Processing during HIV-1 Virion Maturation: A Systems Biology Approach. PLoS Comput. Biol. 2013, 9, e1003103. [CrossRef]

12. Pornillos, O.; Ganser-Pornillos, B.K. Maturation of Retroviruses. Curr. Opin. Virol. 2019, 36, 47-55. [CrossRef]

13. Kucharska, I.; Ding, P.; Zadrozny, K.K.; Dick, R.A.; Summers, M.F.; Ganser-Pornillos, B.K.; Pornillos, O. Biochemical Reconstitution of HIV-1 Assembly and Maturation. J. Virol. 2020, 94, e01844-19. [CrossRef]

14. Bendjennat, M.; Saffarian, S. The Race against Protease Activation Defines the Role of ESCRTs in HIV Budding. PLoS Pathog. 2016, 12, e1005657. [CrossRef]

15. Pornillos, O.; Ganser-Pornillos, B.K.; Yeager, M. Atomic-Level Modelling of the HIV Capsid. Nature 2011, 469, 424-427. [CrossRef]

16. Dick, R.A.; Mallery, D.L.; Vogt, V.M.; James, L.C. IP6 Regulation of HIV Capsid Assembly, Stability, and Uncoating. Viruses 2018, 10, 640. [CrossRef]

17. Mallery, D.L.; Márquez, C.L.; McEwan, W.A.; Dickson, C.F.; Jacques, D.A.; Anandapadamanaban, M.; Bichel, K.; Towers, G.J.; Saiardi, A.; Böcking, T.; et al. IP6 Is an HIV Pocket Factor That Prevents Capsid Collapse and Promotes DNA Synthesis. eLife 2018, 7, e35335. [CrossRef] 
18. Dick, R.A.; Zadrozny, K.K.; Xu, C.; Schur, F.K.M.; Lyddon, T.D.; Ricana, C.L.; Wagner, J.M.; Perilla, J.R.; Ganser-Pornillos, B.K.; Johnson, M.C.; et al. Inositol Phosphates Are Assembly Co-Factors for HIV-1. Nature 2018, 560, 509-512. [CrossRef]

19. Axelrod, D. Cell-Substrate Contacts Illuminated by Total Internal-Reflection Fluorescence. J. Cell Biol. 1981, 89, 141-145. [CrossRef]

20. Axelrod, D. Chapter 7-Total Internal Reflection Fluorescence Microscopy. In Methods in Cell Biology; Correia, J.J., Detrich, H.W., III, Eds.; Academic Press: Cambridge, MA, USA, 2008; Volume 89, pp. 169-221.

21. Jouvenet, N.; Bieniasz, P.D.; Simon, S.M. Imaging the Biogenesis of Individual HIV-1 Virions in Live Cells. Nature 2008, 454, 236-240. [CrossRef]

22. Ivanchenko, S.; Godinez, W.J.; Lampe, M.; Kräusslich, H.-G.; Eils, R.; Rohr, K.; Bräuchle, C.; Müller, B.; Lamb, D.C. Dynamics of HIV-1 Assembly and Release. PLoS Pathog. 2009, 5, e1000652. [CrossRef]

23. Müller, B.; Daecke, J.; Fackler, O.T.; Dittmar, M.T.; Zentgraf, H.; Kräusslich, H.-G. Construction and Characterization of a Fluorescently Labeled Infectious Human Immunodeficiency Virus Type 1 Derivative. J. Virol. 2004, 78, 10803-10813. [CrossRef]

24. Eichorst, J.P.; Chen, Y.; Mueller, J.D.; Mansky, L.M. Distinct Pathway of Human T-Cell Leukemia Virus Type 1 Gag Punctum Biogenesis Provides New Insights into Enveloped Virus Assembly. mBio 2018, 9, e00758-18. [CrossRef]

25. Saffarian, S.; Kirchhausen, T. Differential Evanescence Nanometry: Live-Cell Fluorescence Measurements with 10-Nm Axial Resolution on the Plasma Membrane. Biophys. J. 2008, 94, 2333-2342. [CrossRef]

26. Merrifield, C.J.; Perrais, D.; Zenisek, D. Coupling between Clathrin-Coated-Pit Invagination, Cortactin Recruitment, and Membrane Scission Observed in Live Cells. Cell 2005, 121, 593-606. [CrossRef]

27. Ku, P.-I.; Miller, A.K.; Ballew, J.; Sandrin, V.; Adler, F.R.; Saffarian, S. Identification of Pauses during Formation of HIV-1 Virus Like Particles. Biophys. J. 2013, 105, 2262-2272. [CrossRef]

28. Albrecht, C.; Lakowicz, J.R. Principles of Fluorescence Spectroscopy, 3rd Edition. Anal. Bioanal. Chem. 2008, 390, 1223-1224. [CrossRef]

29. Müller, B.K.; Zaychikov, E.; Bräuchle, C.; Lamb, D.C. Pulsed Interleaved Excitation. Biophys. J. 2005, 89, 3508-3522. [CrossRef]

30. Kapanidis, A.N.; Lee, N.K.; Laurence, T.A.; Doose, S.; Margeat, E.; Weiss, S. Fluorescence-Aided Molecule Sorting: Analysis of Structure and Interactions by Alternating-Laser Excitation of Single Molecules. Proc. Natl. Acad. Sci. USA 2004, 101, 8936-8941. [CrossRef]

31. Giepmans, B.N.G.; Adams, S.R.; Ellisman, M.H.; Tsien, R.Y. The Fluorescent Toolbox for Assessing Protein Location and Function. Science 2006, 312, 217-224. [CrossRef]

32. Fusco, D.; Accornero, N.; Lavoie, B.; Shenoy, S.M.; Blanchard, J.-M.; Singer, R.H.; Bertrand, E. Single MRNA Molecules Demonstrate Probabilistic Movement in Living Mammalian Cells. Curr. Biol. 2003, 13, 161-167. [CrossRef]

33. Hocine, S.; Raymond, P.; Zenklusen, D.; Chao, J.A.; Singer, R.H. Single-Molecule Analysis of Gene Expression Using Two-Color RNA Labeling in Live Yeast. Nat. Meth. 2013, 10, 119-121. [CrossRef]

34. Valegård, K.; Murray, J.B.; Stockley, P.G.; Stonehouse, N.J.; Liljas, L. Crystal Structure of an RNA Bacteriophage Coat ProteinOperator Complex. Nature 1994, 371, 623-626. [CrossRef]

35. Jouvenet, N.; Simon, S.M.; Bieniasz, P.D. Imaging the Interaction of HIV-1 Genomes and Gag during Assembly of Individual Viral Particles. Proc. Natl. Acad. Sci. USA 2009, 106, 19114-19119. [CrossRef]

36. Pocock, G.M.; Becker, J.T.; Swanson, C.M.; Ahlquist, P.; Sherer, N.M. HIV-1 and M-PMV RNA Nuclear Export Elements Program Viral Genomes for Distinct Cytoplasmic Trafficking Behaviors. PLoS Pathog. 2016, 12, e1005565. [CrossRef]

37. Martin-Serrano, J.; Yaravoy, A.; Perez-Caballero, D.; Bieniasz, P.D. Divergent Retroviral Late-Budding Domains Recruit Vacuolar Protein Sorting Factors by Using Alternative Adaptor Proteins. Proc. Natl. Acad. Sci. USA 2003, 100, 12414-12419. [CrossRef]

38. Ku, P.-I.; Bendjennat, M.; Ballew, J.; Landesman, M.B.; Saffarian, S. ALIX Is Recruited Temporarily into HIV-1 Budding Sites at the End of Gag Assembly. PLoS ONE 2014, 9, e96950. [CrossRef]

39. Gupta, S.; Bromley, J.; Saffarian, S. High-Speed Imaging of ESCRT Recruitment and Dynamics during HIV Virus like Particle Budding. PLoS ONE 2020, 15, e0237268. [CrossRef]

40. Bleck, M.; Itano, M.S.; Johnson, D.S.; Thomas, V.K.; North, A.J.; Bieniasz, P.D.; Simon, S.M. Temporal and Spatial Organization of ESCRT Protein Recruitment during HIV-1 Budding. Proc. Natl. Acad. Sci. USA 2014, 111, 12211-12216. [CrossRef]

41. Adell, M.A.Y.; Migliano, S.M.; Upadhyayula, S.; Bykov, Y.S.; Sprenger, S.; Pakdel, M.; Vogel, G.F.; Jih, G.; Skillern, W.; Behrouzi, R.; et al. Recruitment Dynamics of ESCRT-III and Vps4 to Endosomes and Implications for Reverse Membrane Budding. eLife 2017, 6, e31652. [CrossRef]

42. Jouvenet, N.; Zhadina, M.; Bieniasz, P.D.; Simon, S.M. Dynamics of ESCRT Protein Recruitment during Retroviral Assembly. Nat. Cell Biol. 2011, 13, 394-401. [CrossRef]

43. Baumgartel, V.; Ivanchenko, S.; Dupont, A.; Sergeev, M.; Wiseman, P.W.; Krausslich, H.-G.; Brauchle, C.; Muller, B.; Lamb, D.C. Live-Cell Visualization of Dynamics of HIV Budding Site Interactions with an ESCRT Component. Nat. Cell Biol. 2011, 13, 469-474. [CrossRef]

44. Gupta, S.; Bendjennat, M.; Saffarian, S. Abrogating ALIX Interactions Results in Stuttering of the ESCRT Machinery. Viruses 2020, 12, 1032. [CrossRef]

45. Johnson, D.S.; Bleck, M.; Simon, S.M. Timing of ESCRT-III Protein Recruitment and Membrane Scission during HIV-1 Assembly. eLife 2018, 7, e36221. [CrossRef]

46. Márquez, C.L.; Lau, D.; Walsh, J.; Shah, V.; McGuinness, C.; Wong, A.; Aggarwal, A.; Parker, M.W.; Jacques, D.A.; Turville, S.; et al. Kinetics of HIV-1 Capsid Uncoating Revealed by Single-Molecule Analysis. eLife 2018, 7, e34772. [CrossRef] 
47. Mallery, D.L.; Faysal, K.M.R.; Kleinpeter, A.; Wilson, M.S.C.; Vaysburd, M.; Fletcher, A.J.; Novikova, M.; Böcking, T.; Freed, E.O.; Saiardi, A.; et al. Cellular IP(6) Levels Limit HIV Production While Viruses That Cannot Efficiently Package IP(6) Are Attenuated for Infection and Replication. Cell Rep. 2019, 29, 3983-3996. [CrossRef]

48. Hell, S.W.; Wichmann, J. Breaking the Diffraction Resolution Limit by Stimulated Emission: Stimulated-Emission-Depletion Fluorescence Microscopy. Opt. Lett. 1994, 19, 780-782. [CrossRef]

49. Hell, S.; Stelzer, E.H.K. Properties of a 4pi Confocal Fluorescence Microscope. J. Opt. Soc. Am. A Opt. Image Sci. Vis. 1992, 9 , 2159-2166. [CrossRef]

50. Gustafsson, M.G.L. Nonlinear Structured-Illumination Microscopy: Wide-Field Fluorescence Imaging with Theoretically Unlimited Resolution. Proc. Natl. Acad. Sci. USA 2005, 102, 13081-13086. [CrossRef]

51. Thompson, R.E.; Larson, D.R.; Webb, W.W. Precise Nanometer Localization Analysis for Individual Fluorescent Probes. Biophys. J. 2002, 82, 2775-2783. [CrossRef]

52. Peterman, E.J.G.; Brasselet, S.; Moerner, W.E. The Fluorescence Dynamics of Single Molecules of Green Fluorescent Protein. J. Phys. Chem. A 1999, 103, 10553-10560. [CrossRef]

53. Betzig, E.; Patterson, G.H.; Sougrat, R.; Lindwasser, O.W.; Olenych, S.; Bonifacino, J.S.; Davidson, M.W.; Lippincott-Schwartz, J.; Hess, H.F. Imaging Intracellular Fluorescent Proteins at Nanometer Resolution. Science 2006, 313, 1642-1645. [CrossRef] [PubMed]

54. Rust, M.J.; Bates, M.; Zhuang, X.W. Sub-Diffraction-Limit Imaging by Stochastic Optical Reconstruction Microscopy (STORM). Nat. Methods 2006, 3, 793-795. [CrossRef] [PubMed]

55. Xu, K.; Babcock, H.P.; Zhuang, X. Dual-Objective STORM Reveals Three-Dimensional Filament Organization in the Actin Cytoskeleton. Nat. Meth. 2012, 9, 185-188. [CrossRef]

56. Mlodzianoski, M.J.; Schreiner, J.M.; Callahan, S.P.; Smolkova, K.; Dlaskova, A.; Santorova, J.; Jezek, P.; Bewersdorf, J. Sample Drift Correction in 3D Fluorescence Photoactivation Localization Microscopy. Opt. Express 2011, 19, 15009-15019. [CrossRef]

57. Shtengel, G.; Galbraith, J.A.; Galbraith, C.G.; Lippincott-Schwartz, J.; Gillette, J.M.; Manley, S.; Sougrat, R.; Waterman, C.M.; Kanchanawong, P.; Davidson, M.W.; et al. Interferometric Fluorescent Super-Resolution Microscopy Resolves 3D Cellular Ultrastructure. Proc. Natl. Acad. Sci. USA 2009, 106, 3125-3130. [CrossRef]

58. Prescher, J.; Baumgärtel, V.; Ivanchenko, S.; Torrano, A.A.; Bräuchle, C.; Müller, B.; Lamb, D.C. Super-Resolution Imaging of ESCRT-Proteins at HIV-1 Assembly Sites. PLoS Pathog. 2015, 11, e1004677. [CrossRef]

59. Van Engelenburg, S.B.; Shtengel, G.; Sengupta, P.; Waki, K.; Jarnik, M.; Ablan, S.D.; Freed, E.O.; Hess, H.F.; Lippincott-Schwartz, J. Distribution of ESCRT Machinery at HIV Assembly Sites Reveals Virus Scaffolding of ESCRT Subunits. Science 2014, 343, 653-656. [CrossRef]

60. Chojnacki, J.; Staudt, T.; Glass, B.; Bingen, P.; Engelhardt, J.; Anders, M.; Schneider, J.; Müller, B.; Hell, S.W.; Kräusslich, H.-G. Maturation-Dependent HIV-1 Surface Protein Redistribution Revealed by Fluorescence Nanoscopy. Science 2012, 338, 524-528. [CrossRef]

61. Floderer, C.; Masson, J.-B.; Boilley, E.; Georgeault, S.; Merida, P.; El Beheiry, M.; Dahan, M.; Roingeard, P.; Sibarita, J.-B.; Favard, C.; et al. Single Molecule Localisation Microscopy Reveals How HIV-1 Gag Proteins Sense Membrane Virus Assembly Sites in Living Host CD4 T Cells. Sci. Rep. 2018, 8, 16283. [CrossRef]

62. Pezeshkian, N.; Groves, N.S.; van Engelenburg, S.B. Single-Molecule Imaging of HIV-1 Envelope Glycoprotein Dynamics and Gag Lattice Association Exposes Determinants Responsible for Virus Incorporation. Proc. Natl. Acad. Sci. USA 2019, 116, 25269-25277. [CrossRef]

63. Schimer, J.; Pávová, M.; Anders, M.; Pachl, P.; Šácha, P.; Cígler, P.; Weber, J.; Majer, P.; Řezáčová, P.; Kräusslich, H.-G.; et al. Triggering HIV Polyprotein Processing by Light Using Rapid Photodegradation of a Tight-Binding Protease Inhibitor. Nat. Commun. 2015, 6. [CrossRef] [PubMed]

64. Hanne, J.; Göttfert, F.; Schimer, J.; Anders-Össwein, M.; Konvalinka, J.; Engelhardt, J.; Müller, B.; Hell, S.W.; Kräusslich, H.-G. Stimulated Emission Depletion Nanoscopy Reveals Time-Course of Human Immunodeficiency Virus Proteolytic Maturation. ACS Nano 2016, 10, 8215-8222. [CrossRef] [PubMed]

65. Saha, I.; Saffarian, S. Dynamics of the HIV Gag Lattice Detected by Localization Correlation Analysis and Time-Lapse IPALM. Biophys. J. 2020, 119, 1-12. [CrossRef]

66. Kubo, R. The Fluctuation-Dissipation Theorem. Rep. Prog. Phys. 1966, 29, 255-284. [CrossRef]

67. Magde, D.; Elson, E.L.; Webb, W.W. Fluorescence Correlation Spectroscopy. II. An Experimental Realization. Biopolymers 1974, 13, 29-61. [CrossRef]

68. Johnson, D.C.; Schlesinger, M.J.; Elson, E.L. Fluorescence Photobleaching Recovery Measurements Reveal Differences in Envelopment of Sindbis and Vesicular Stomatitis Viruses. Cell 1981, 23, 423-431. [CrossRef]

69. Rigler, R. Fluorescence Correlations, Single Molecule Detection and Large Number Screening Applications in Biotechnology. J. Biotechnol. 1995, 41, 177-186. [CrossRef]

70. Qian, H.; Elson, E. Distribution of Molecular Aggregation by Analysis of Fluctuation Moments. Proc. Natl. Acad. Sci. USA 1990, 87, 5479-5483. [CrossRef]

71. Kask, P.; Palo, K.; Ullmann, D.; Gall, K. Fluorescence-Intensity Distribution Analysis and Its Application in Biomolecular Detection Technology. Proc. Natl. Acad. Sci. USA 1999, 96, 13756-13761. [CrossRef] 
72. Chen, Y.; Muller, J.D.; So, P.T.C.; Gratton, E. The Photon Counting Histogram in Fluorescence Fluctuation Spectroscopy. Biophys. J. 1999, 77, 553-567. [CrossRef]

73. Digman, M.A.; Gratton, E. Imaging Barriers to Diffusion by Pair Correlation Functions. Biophys. J. 2009, 97, 665-673. [CrossRef] [PubMed]

74. Brown, C.M.; Dalal, R.B.; Hebert, B.; Digman, M.A.; Horwitz, A.R.; Gratton, E. Raster Image Correlation Spectroscopy (RICS) for Measuring Fast Protein Dynamics and Concentrations with a Commercial Laser Scanning Confocal Microscope. J. Microsc. 2008, 229, 78-91. [CrossRef] [PubMed]

75. Hebert, B.; Costantino, S.; Wiseman, P.W. Spatiotemporal Image Correlation Spectroscopy (STICS) Theory, Verification, and Application to Protein Velocity Mapping in Living CHO Cells. Biophys. J. 2005, 88, 3601-3614. [CrossRef] [PubMed]

76. Heinze, K.G.; Rarbach, M.; Jahnz, M.; Schwille, P. Two-Photon Fluorescence Coincidence Analysis: Rapid Measurements of Enzyme Kinetics. Biophys. J. 2002, 83, 1671-1681. [CrossRef]

77. Ries, J.; Schwille, P. Fluorescence Correlation Spectroscopy. BioEssays 2012, 34, 361-368. [CrossRef] [PubMed]

78. Palmer, A., III; Thompson, N. Molecular Aggregation Characterized by High Order Autocorrelation in Fluorescence Correlation Spectroscopy. Biophys. J. 1987, 52, 257-270. [CrossRef]

79. Ge, H.; Qian, H. Physical Origins of Entropy Production, Free Energy Dissipation, and Their Mathematical Representations. Phys. Rev. E 2010, 81, 051133. [CrossRef]

80. Qian, H.; Saffarian, S.; Elson, E.L. Concentration Fluctuations in a Mesoscopic Oscillating Chemical Reaction System. Proc. Natl. Acad. Sci. USA 2002, 99, 10376-10381. [CrossRef]

81. Qian, H. Motor Protein with Nonequilibrium Potential: Its Thermodynamics and Efficiency. Phys. Rev. E 2004, 69. [CrossRef]

82. Wang, J.; Xu, L.; Wang, E. Potential Landscape and Flux Framework of Nonequilibrium Networks: Robustness, Dissipation, and Coherence of Biochemical Oscillations. Proc. Natl. Acad. Sci. USA 2008, 105, 12271-12276. [CrossRef]

83. Wang, J.; Li, C.; Wang, E. Potential and Flux Landscapes Quantify the Stability and Robustness of Budding Yeast Cell Cycle Network. Proc. Natl. Acad. Sci. USA 2010, 107, 8195-8200. [CrossRef] [PubMed]

84. Saha, I.; Saffarian, S. Interferometric Fluorescence Cross Correlation Spectroscopy. PLoS ONE 2019, 14, e0225797. [CrossRef] [PubMed]

85. Ako-Adjei, D.; Johnson, M.C.; Vogt, V.M. The Retroviral Capsid Domain Dictates Virion Size, Morphology, and Coassembly of Gag into Virus-Like Particles. J. Virol. 2005, 79, 13463-13472. [CrossRef] [PubMed]

86. Larson, D.R.; Ma, Y.M.; Vogt, V.M.; Webb, W.W. Direct Measurement of Gag-Gag Interaction during Retrovirus Assembly with FRET and Fluorescence Correlation Spectroscopy. J. Cell Biol. 2003, 162, 1233-1244. [CrossRef] [PubMed]

87. Chen, Y.; Wu, B.; Musier-Forsyth, K.; Mansky, L.M.; Mueller, J.D. Fluorescence Fluctuation Spectroscopy on Viral-Like Particles Reveals Variable Gag Stoichiometry. Biophys. J. 2009, 96, 1961-1969. [CrossRef] [PubMed]

88. Briggs, J.A.G.; Riches, J.D.; Glass, B.; Bartonova, V.; Zanetti, G.; Kräusslich, H.-G. Structure and Assembly of Immature HIV. Proc. Natl. Acad. Sci. USA 2009, 106, 11090-11095. [CrossRef] [PubMed]

89. Hendrix, J.; Baumgärtel, V.; Schrimpf, W.; Ivanchenko, S.; Digman, M.A.; Gratton, E.; Kräusslich, H.-G.; Müller, B.; Lamb, D.C. Live-Cell Observation of Cytosolic HIV-1 Assembly Onset Reveals RNA-Interacting Gag Oligomers. J. Cell Biol. 2015, 210, 629-646. [CrossRef]

90. Favard, C.; Chojnacki, J.; Merida, P.; Yandrapalli, N.; Mak, J.; Eggeling, C.; Muriaux, D. HIV-1 Gag Specifically Restricts PI(4,5)P2 and Cholesterol Mobility in Living Cells Creating a Nanodomain Platform for Virus Assembly. Sci. Adv. 2019, 5, eaaw8651. [CrossRef]

91. Yandrapalli, N.; Lubart, Q.; Tanwar, H.S.; Picart, C.; Mak, J.; Muriaux, D.; Favard, C. Self Assembly of HIV-1 Gag Protein on Lipid Membranes Generates PI(4,5)P(2)/Cholesterol Nanoclusters. Sci. Rep. 2016, 6, 39332. [CrossRef]

92. Clegg, R.M. Fluorescence Resonance Energy Transfer. Curr. Opin. Biotechnol. 1995, 6, 103-110. [CrossRef]

93. Tan, E.; Wilson, T.J.; Nahas, M.K.; Clegg, R.M.; Lilley, D.M.J.; Ha, T. A Four-Way Junction Accelerates Hairpin Ribozyme Folding via a Discrete Intermediate. Proc. Natl. Acad. Sci. USA 2003, 100, 9308. [CrossRef] [PubMed]

94. McKinney, S.A.; Freeman, A.D.J.; Lilley, D.M.J.; Ha, T. Observing Spontaneous Branch Migration of Holliday Junctions One Step at a Time. Proc. Natl. Acad. Sci. USA 2005, 102, 5715-5720. [CrossRef] [PubMed]

95. Myong, S.; Cui, S.; Cornish, P.V.; Kirchhofer, A.; Gack, M.U.; Jung, J.U.; Hopfner, K.-P.; Ha, T. Cytosolic Viral Sensor RIG-I Is a 5'-Triphosphate-Dependent Translocase on Double-Stranded RNA. Science 2009, 323, 1070. [CrossRef] [PubMed]

96. Munro, J.B.; Nath, A.; Färber, M.; Datta, S.A.K.; Rein, A.; Rhoades, E.; Mothes, W. A Conformational Transition Observed in Single HIV-1 Gag Molecules during In Vitro Assembly of Virus-Like Particles. J. Virol. 2014, 88, 3577-3585. [CrossRef]

97. Munro, J.B.; Gorman, J.; Ma, X.; Zhou, Z.; Arthos, J.; Burton, D.R.; Koff, W.C.; Courter, J.R.; Smith, A.B.; Kwong, P.D.; et al. Conformational Dynamics of Single HIV-1 Envelope Trimers on the Surface of Native Virions. Science 2014, 346, 759-763. [CrossRef]

98. Lu, M.; Ma, X.; Castillo-Menendez, L.R.; Gorman, J.; Alsahafi, N.; Ermel, U.; Terry, D.S.; Chambers, M.; Peng, D.; Zhang, B.; et al. Associating HIV-1 Envelope Glycoprotein Structures with States on the Virus Observed by SmFRET. Nature 2019, 568, 415-419. [CrossRef]

99. Lu, M.; Ma, X.; Mothes, W. Illuminating the Virus Life Cycle with Single-Molecule FRET Imaging. Adv. Virus Res. 2019, 105, 239-273.

100. Francis, A.C.; Melikyan, G.B. Live-Cell Imaging of Early Steps of Single HIV-1 Infection. Viruses 2018, 10, 275. [CrossRef] 
101. Melikyan, G.B. HIV Entry: A Game of Hide-and-Fuse? Curr. Opin. Virol. 2014, 4, 1-7. [CrossRef]

102. Mamede, J.I.; Hope, T.J. Detection and Tracking of Dual-Labeled HIV Particles Using Wide-Field Live Cell Imaging to Follow Viral Core Integrity. In HIV Protocols; Prasad, V.R., Kalpana, G.V., Eds.; Springer: New York, NY, USA, 2016; pp. 49-59.

103. Inamdar, K.; Floderer, C.; Favard, C.; Muriaux, D. Monitoring HIV-1 Assembly in Living Cells: Insights from Dynamic and Single Molecule Microscopy. Viruses 2019, 11, 72. [CrossRef] 